\section{A) Check for updates}

Cite this: Inorg. Chem. Front., 2020, 7, 4062

\title{
A bioorthogonal time-resolved luminogenic probe for metabolic labelling and imaging of glycans $\dagger$
}

\author{
Judun Zheng, ${ }^{\text {a,d }}$ Qiuqiang Zhan, ${ }^{b}$ Lijun Jiang, ${ }^{c}$ Da Xing, (D) *a Tao Zhang (D)*a and \\ Ka-Leung Wong (D)*c
}

\begin{abstract}
The use of bioorthogonal fluorogenic probes is superior to labelling and imaging of biomolecules in live cells and organisms, although overcoming the limitation of autofluorescence is still a challenge for current probes to achieve high illumination resolution of the target of interest. We herein demonstrate a functionalized terbium complex Tb-1 that is stable and biocompatible to enable bioorthogonal ligation with engineered cell-surface glycans for providing responsive luminescence. A luminescence resonance energy transfer (LRET) quencher with bioorthogonal properties is strategically incorporated into a tripodal terbium complex with low toxicity, which can undergo a click-cycloaddition reaction with a cyclooctene to completely change the electronic structure of the quencher, resulting in a much less efficient LRET but a 5-fold enhancement in the long-lived terbium emission intensity. This work therefore establishes a time-resolved platform that enables labelling and imaging of the biomolecules of interest.
\end{abstract}

Received 21st June 2020,

Accepted 31st August 2020

DOI: 10.1039/d0qi00728e

rsc.li/frontiers-inorganic and the cell surface glycans can be labeled without any interference or distress to the physiological environment. ${ }^{9}$ There are reports of various types of fluorogenic bioorthogonal reporters, ${ }^{10,11}$ such as tetrazine, ${ }^{12,13}$ azide,${ }^{14,15}$ alkenes, ${ }^{16,17}$ cycloalkynes ${ }^{18,19}$ and cyclopropenes,${ }^{20}$ that exhibit specific and click reactions to perform bioorthogonal ligation. However, the major drawback associated with conventional fluorescent dyes lies in the interference of autofluorescence.

Various imaging techniques have been utilized in the imaging of glycans, including stochastic optical reconstruction microscopy (STORM) imaging, ${ }^{21}$ magnetic resonance (MR) imaging $^{22}$ and fluorescence imaging. ${ }^{23-26}$ The development of both bioorthogonal chemical reporters and labelling agents has gathered pace in the past decade as researchers hope to increase their specificity and reactivity by introducing new pairs of bioorthogonal conjugators and to gain better resolution in the visualization of the substrate.

Trivalent lanthanides, in particular europium(III) and terbium(III), have been commonly used as emission centers due to their characteristic emission profiles and long emission lifetimes ( $\mu \mathrm{s}-\mathrm{ms}$ time frame). ${ }^{27-30}$ The fingerprint emission bands allow differentiation from the broad and structureless emission bands of organic chromophores and convincingly distinguish lanthanide emissions from shortlived biological autofluorescence (ns-based) using timeresolved measurements. ${ }^{31-33}$ The technique of time-resolved spectroscopy makes use of a time-gated system to delay data acquisition of pulse-excited emission signals so that the detection window is only opened after the unwanted emissions have faded, and the desired longer-lived emission(s) are distinctly 
detected. ${ }^{34-36}$ The lanthanide probes have gained great momentum for application in biological detection and imaging, especially the "switch-off" strategy based on the principle of photoinduced electron transfer or antenna-analyte electron transfer. ${ }^{27,37}$ Recently, lanthanide complexes incorporated with several functional groups have also been covalently linked to metabolically engineered substrates via bioorthogonal ligation to perform time-resolved imaging and labelling of cell surface glycans in order to obtain more information on how glycans regulate progression. ${ }^{38-40}$ However, these complexes with "always-on" luminescence signals suffer from the interference of unremoved complexes. Therefore, to obtain high signal/background (S/B) ratios, the development of a luminogenic lanthanide probe that can be activated by a bioorthogonal reaction is highly desirable. Furthermore, timeresolved luminescence spectroscopy allows the probing of the excited state dynamics and deactivation pathways of our designed imaging complexes, offering complementary evidence for our bioorthogonal ligation mechanism.

To improve the imaging efficacy via combining bioorthogonal chemistry with lanthanide emission, herein, we report the design and synthesis of a luminogenic tetrazine-based terbium(III) probe (Tb-1, Scheme 1). Tb-1 was found to be activated via a bioorthogonal tetrazine ligation and exhibited dramatic enhancement of long-lived luminescence (5-fold) upon cycloaddition reaction with a strained trans-cyclooctene (TCO). Notably, Tb-1 could enable robust and sensitive detection of cyclooctene-modified glycome under no-wash conditions in living cells and zebrafish.

\section{Results and discussion}

As the absorption of tetrazine overlaps well with the emission of $\mathrm{Tb}^{3+}$ (Fig. $\mathrm{S} 1 \dagger$ ), we rationally hypothesized that the tetrazinefunctional group could quench the luminescence of terbium via luminescence resonance energy transfer (LRET) between the terbium compound and the tetrazine moiety. To confirm the hypothesis, we also synthesized and characterized a reference complex Tb-M without the tetrazine moiety together with the probe $\mathbf{T b}-\mathbf{1}$ based on a 7-substituted quinolinone antenna (Fig. 1 and Fig. S2-S13†).

Typically, Tb-M and $\mathbf{T b} \mathbf{- 1}$ exhibited a similar quinolinone absorption band, located at 348 and $346 \mathrm{~nm}$, respectively

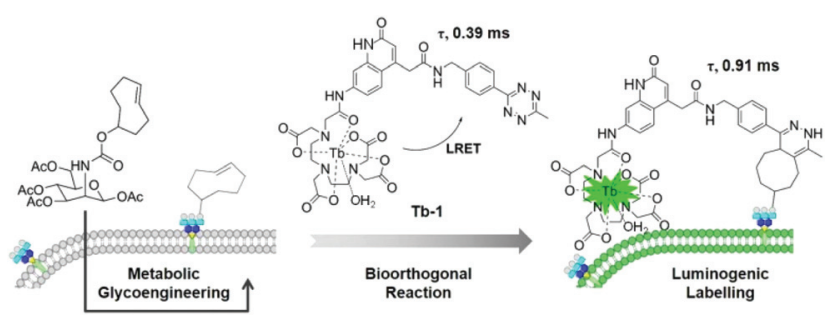

Scheme 1 Schematic illustration of the bioorthogonal time-resolved luminogenic probe Tb-1 for metabolic labelling and imaging of glycans.

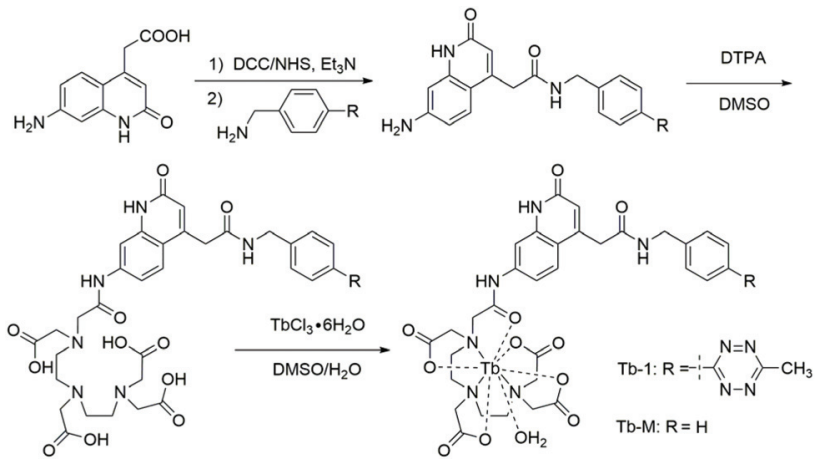

Fig. 1 The synthesis route to Tb-M and Tb-1.

Table 1 Photophysical parameters of the $\mathrm{Tb}($ III) complexes

\begin{tabular}{llllll}
\hline & $\begin{array}{l}\lambda_{\mathrm{abs}}{ }^{a} / \\
\mathrm{nm}\end{array}$ & $\begin{array}{l}\varepsilon^{b} / \\
\mathrm{M}^{-1} \mathrm{~cm}^{-1}\end{array}$ & $\begin{array}{l}\tau\left(\mathrm{H}_{2} \mathrm{O}\right)^{c} / \\
\mathrm{ms}\end{array}$ & $\begin{array}{l}\tau\left(\mathrm{D}_{2} \mathrm{O}\right)^{c} / \\
\mathrm{ms}\end{array}$ & $\Phi^{d} / \%$ \\
\hline $\mathbf{T b}-\mathbf{M}$ & 348 & 12113 & 1.06 & 1.32 & $10.7 \pm 0.6$ \\
$\mathbf{T b - 1}$ & 346,522 & 10188,1132 & 0.39 & 0.89 & $1.0 \pm 0.8$ \\
$\mathbf{T b - 1}+\mathrm{TCO}^{e}$ & 347 & 10312 & 0.91 & - & $9.0 \pm 0.5$
\end{tabular}

${ }^{a}$ Measured in DI $\mathrm{H}_{2}$ O. ${ }^{b}$ Absorption coefficient, $298 \mathrm{~K} .{ }^{c} \mathrm{~Tb}$ emission decay $\left(\lambda_{\mathrm{em}}=545 \mathrm{~nm},{ }^{5} \mathrm{D}_{4} \rightarrow{ }^{7} \mathrm{~F}_{5}, \lambda_{\mathrm{ex}}=340 \mathrm{~nm}, 5 \mathrm{mM}\right)$; hydration number of $\mathrm{Tb}(\mathrm{III})$ complexes, $q=1.2 \times\left[k\left(\mathrm{H}_{2} \mathrm{O}\right)-k\left(\mathrm{D}_{2} \mathrm{O}\right)-0.25\right], k=$ $\tau^{-1.41,42} d$ Overall Tb emission quantum yield in $\mathrm{H}_{2} \mathrm{O}$, determined by integrating sphere. ${ }^{43} e$ With the addition of 20 equivalents TCO.

(Table 1). Unlike the colorless $\mathbf{T b}-\mathbf{M}$, the pale red $\mathbf{T b} \mathbf{- 1}$ exhibited an absorption band centered at $522 \mathrm{~nm},{ }^{44,45}$ which is attributed to the tetrazine moiety (Table 1). On the other hand, there were no energy transfer pathways between the tetrazine moiety and antenna ligand (Fig. S14 $\dagger$ ). The emission quantum yield ( $\lambda_{\text {ex }}=340 \mathrm{~nm}$ ) of $\mathbf{T b}-1$ showed a dramatic difference to that of Tb-M. Tb-M exhibited a strong green emission with a quantum yield of $10.7 \%$ in aqueous solution, while Tb-1 showed only very weak $\mathrm{Tb}$ emission under identical experimental conditions $(\Phi=1.0 \%)$. The room temperature emission spectra of $\mathbf{T b}-\mathbf{M}$ and $\mathbf{T b}-\mathbf{1}$ under the same excitation wavelength as the antenna ligand are given in Fig. S15, $\dagger$ which shows the characteristic ${ }^{5} \mathrm{D}_{4} \rightarrow{ }^{7} \mathrm{~F}_{J}(J=3,4,5,6)$ transitions of $\mathrm{Tb}^{3+}$. The ratios of the ${ }^{5} \mathrm{D}_{4} \rightarrow{ }^{7} \mathrm{~F}_{J}$ emissions from $\mathbf{T b}-\mathbf{M}$ and $\mathbf{T b}$ 1 indicate that both complexes have similar coordination geometry. As for Tb-1, there were two steps in the energy transfer pathways including the energy transferred from antenna ligands to $\mathrm{Tb}^{3+}$, and further from $\mathrm{Tb}^{3+}$ to tetrazine. On the basis of the reported methods, ${ }^{29,46}$ the sensitization and LRET efficiency of these was obtained as $63.21 \%$ and $46.5 \%$, respectively. By measuring the phosphorescence spectra of $\mathbf{L a}-\mathbf{H}$ and La-1 obtained at $77 \mathrm{~K}$, we found that the two complexes exhibited a similar phosphorescence band of the antenna ligand at $445 \mathrm{~nm}$ (Fig. S16†), indicating that the energy level of the $\mathrm{T}_{1}$ excited states of the antenna chromophores are around $22472 \mathrm{~cm}^{-1}$ and fall in the optimum energy transfer range of the ${ }^{5} \mathrm{D}_{4}$ excited state of $\mathrm{Tb}^{3+}\left(20400 \mathrm{~cm}^{-1}\right)$. The quenched $\mathrm{Tb}^{3+}$ emission in Tb-1 is thereby attributed to LRET energy transfer 
from the excited $\mathrm{Tb}^{3+}$ state to the excited state of tetrazine (19157 $\mathrm{cm}^{-1}$ ). Once the tetrazine binds with TCO, the excited state level of tetrazine-TCO would be higher than that of tetrazine, which could block the LRET process, resulting in enhancement of the $\mathrm{Tb}^{3+}$ luminescence emission. And the proposed energy transfer mechanism of $\mathbf{T b - 1}$ is summarized in Fig. S17. $\dagger$

Considering that the cycloadduct of tetrazine has almost no absorption in the region of interest, the LRET degree should be controlled by the bioorthogonal reaction of tetrazine and TCO (Fig. 2a). The absorption of $\mathbf{T b}-\mathbf{1}$ in the range of 500-600 nm was then found to disappear upon titration, and simultaneously, the solution turned from red to colorless, indicating the loss of the tetrazine adduct, further confirming that the quenching of luminescence was attributed to LRET (Fig. 2b and Fig. S18†). The time-gated spectra of Tb-1 upon titrating with TCO clearly show that the probe responded well and achieved a 5-fold increase in luminescence intensity (Fig. 2c). The luminescence lifetime was extended from 0.39 to $0.91 \mathrm{~ms}$ in PBS buffer solution, which is sufficiently long to eliminate background fluorescence (Fig. 2d, Table 1 and Fig. S19†) and the number of metal-bound water molecules in solution can be calculated to be one via reported methods, which was further confirmed by the Fourier transform infrared (FTIR) spectrum, demonstrating that there is no difference in
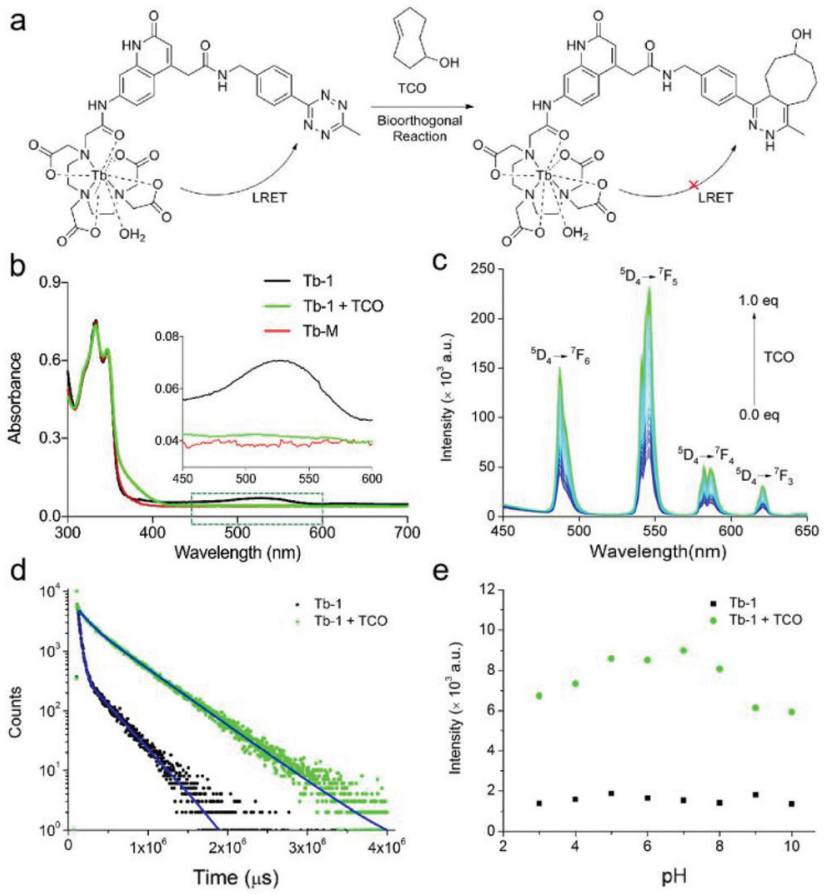

Fig. 2 (a) Schematic of sensing bioorthogonal reaction of luminogenic Tb-1 with TCO based on the LRET mechanism. (b) The absorbance spectra of Tb-M, and Tb-1 in the absence or presence of TCO. (c) Timegated luminescence spectra of Tb-1 titrating with TCO $\left(\lambda_{\mathrm{ex}}=340 \mathrm{~nm}\right)$. (d) Decay time curves of the ${ }^{5} D_{4} \rightarrow{ }^{7} F_{5}$ emission of $\mathrm{Tb}^{3+}(10 \mu \mathrm{M})$ in the absence and presence of TCO $(20 \mu \mathrm{M})$. (e) The luminescence intensity $\left(\lambda_{\mathrm{em}}=545 \mathrm{~nm}\right)$ of complex Tb-1 reacted with TCO in various $\mathrm{pH}$ buffers. solvent quenching (Fig. S20 $\left.{ }^{4}\right){ }^{47}$ A linear relationship between the emission intensity at $545 \mathrm{~nm}$ and the concentration of TCO from $0-4 \mu \mathrm{M}$ was observed, and the response limit of $\mathbf{T b}$ 1 for TCO in solution was then determined to be $19.6 \mathrm{nM}$ by means of the reported method (Fig. S21 ${ }^{48}{ }^{48}$

Next, the sensing of Tb-1 towards TCO was measured in a physiological environment with the $\mathrm{pH}$ ranging from 8.0 to 5.0 by monitoring the $\mathrm{Tb}^{3+}$ luminescence (Fig. 2e). The results showed that $\mathbf{T b} \mathbf{- 1}$ showed excellent responsiveness to TCO in such a physiological environment, despite the fact that $\mathrm{pH}$ dependent emission was observed below 5.0 and over 8.0 due to the protonation and hydrolysis of the organic antenna. ${ }^{49}$ Meanwhile, the biostability of $\mathbf{T b}-\mathbf{1}$ was also evaluated by measuring its luminescence in PBS solution under various conditions: PBS solution containing different serum concentrations (from 0 to $50 \%$ ) were kept for different times (from 1 to $24 \mathrm{~h}$ ). Persistent luminescence of the $\mathbf{T b} \mathbf{b} \mathbf{1}$ under these conditions was observed (Fig. S22†), indicating its high stability in the simulated physiological environments. Besides, the interference from unsaturated fatty acids including oleic acid or linoleic acid was studied by recording the luminescence intensity changes. And only the addition of TCO resulted in a prominent increase in the luminescence emission intensity within $60 \mathrm{~min}$ (Fig. S23†), which was because of the faster kinetics of reaction between tetrazine and TCO $\left(3910 \mathrm{M}^{-1} \mathrm{~s}^{-1}\right.$, Fig. S24†) compared with the tetrazine and alkene. ${ }^{50}$ These performances strongly suggest that the bio-stable probe Tb-1 could be used as a preferable tool with higher sensitivity and a larger turn-on luminescence response to TCO.

Having shown that Tb-1 responds well to TCO in vitro, we then evaluated the capability of the probe in the labelling of specific biomolecules, glycans, in the living cells. The cytotoxicity of Tb-1 was firstly tested on different cell lines (such as A549 and EMT 6 or LO2 cells) by using the standard cell counting kit 8 (CCK-8) assays (Fig. S25 $\dagger$ ). The complex appeared to be quite nontoxic, with $\mathrm{IC}_{50}$ values of $c a .1 \mathrm{mmol}$ : a level far above the normal working concentration of a probe. Then, A549 cells were treated with $50 \mu \mathrm{M}$ peracetylated $N$-TCO-mannosamine ( $\left.\mathrm{Ac}_{4} \mathrm{ManNTCO}\right)$ that would be metabolically converted into the corresponding alkynylsialic acid bearing TCO groups on the cell surface for $72 \mathrm{~h}$. Control cells were incubated with peracetylated mannosamine $\left(\mathrm{Ac}_{4} \mathrm{ManNH}_{2}\right)$. After this, A549 cells pretreated with the $\mathrm{Ac}_{4} \mathrm{ManNTCO}$ or $\mathrm{Ac}_{4} \mathrm{ManNH}_{2}$ were incubated with $\mathbf{T b}-\mathbf{1}$ for $3 \mathrm{~h}$, and then imaging by fluorescence microscopy was performed without washing. The two-photon photophysical properties of some quinolinone-sensitized $\mathrm{Tb}$ complexes have been studied previously, further providing a means of reducing the interference from other biological matter by utilizing low energy near infrared (NIR) excitation. ${ }^{51-54}$ Two-photon excitation of Tb-1 with a NIR laser can also induce the typical Tb-1 emission in the presence of TCO at $298 \mathrm{~K}$ (Fig. S26 $\dagger$ ). Compared with Fig. 2c, a broad band arising from the intraligand transition is observed, and this band overlaps with the standard set of well-resolved narrow emission bands owing to the $\mathrm{Tb}^{3+}$ centered transitions due to the quinolinone fluorescence or phosphorescence at 


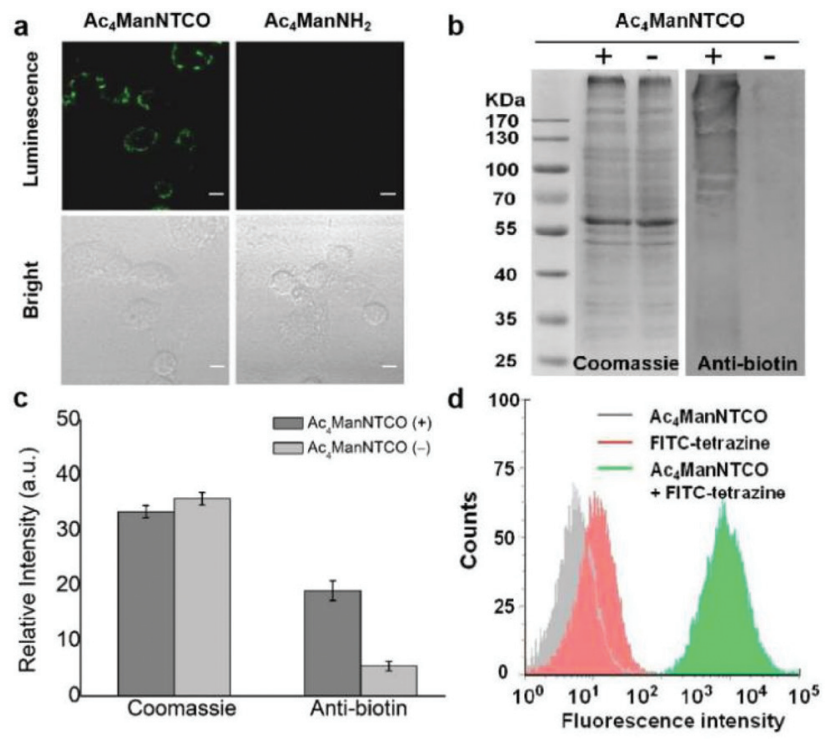

Fig. 3 (a) Two-photon luminescence images of A549 cells after treatment with $\mathrm{Ac}_{4} \mathrm{ManNTCO}$ or $\mathrm{Ac}_{4} \mathrm{ManNH}_{2}(50 \mu \mathrm{M})$ for three days and further incubation with Tb-1 $(50 \mu \mathrm{M})$ for $3 \mathrm{~h}$. (b) Western blot analysis of lysates from $\mathrm{A} 549$ cells treated with $\mathrm{Ac}_{4} \mathrm{ManNTCO}$ or $\mathrm{Ac}_{4} \mathrm{ManNH}_{2}$ $(50 \mu \mathrm{M})$. (c) Corresponding quantified intensity from (b). (d) Flow cytometry analysis of A549 cells pretreated with $\mathrm{Ac}_{4}$ ManNTCO or not, followed by incubation with FITC-tetrazine.

$298 \mathrm{~K}$, which would only be partially quenched in the emission spectrum recorded at $77 \mathrm{~K} .{ }^{47}$ As shown in Fig. 3a, A549 cells treated with $\mathrm{Ac}_{4} \mathrm{ManNTCO}$ and Tb-1 displayed a strong luminescence on the cell surface as observed by two-photon $\left(\lambda_{\mathrm{ex}}=\right.$ $730 \mathrm{~nm}$ ) confocal microscopy, while the control cells labelled with $\mathrm{Ac}_{4} \mathrm{ManNH}_{2}$ exhibited only a very weak emission. The expression of TCO groups on sialoglycoproteins was then studied by Coomassie Brilliant Blue staining and western blot analysis (Fig. $3 \mathrm{~b}$ and c). The results revealed that abundant TCO groups were generated via metabolic glycoengineering of proteins on the cell surface. The significant cell membrane labelling and imaging over the background is attributed to the good luminogenic behavior of Tb-1. Flow cytometry analysis of the A549 cells treated with $\mathrm{Ac}_{4} \mathrm{ManNTCO}$ and fluorescein isothiocyanate (FITC)-tetrazine further confirmed that the cells modified with TCO groups can be labelled and light-up dramatically (Fig. 3d).

Next, our tetrazine-functionalized luminogenic probe $\mathbf{T b} \mathbf{- 1}$ was further employed for glycome imaging in living systems, and zebrafish was selected as a typical proof-of-concept visualization model due to its advantages of well characterized morphology, optical transparency and high homology with mammals. ${ }^{55}$ In order to label sialylated glycans in zebrafish, its embryos were microinjected with $10 \mathrm{~nL}$ medium containing $5 \mathrm{mM} \mathrm{Ac}$ ManNTCO for $72 \mathrm{~h}$ post-fertilization, resulting in metabolic labelling of O-linked sialylated glycans with TCO. We then incubated the embryos with Tb-1 for $3 \mathrm{~h}$ and imaged them by confocal microscopy (Fig. 4a and b). Notably, a very sharp luminescence signal was observed in the enveloping cell
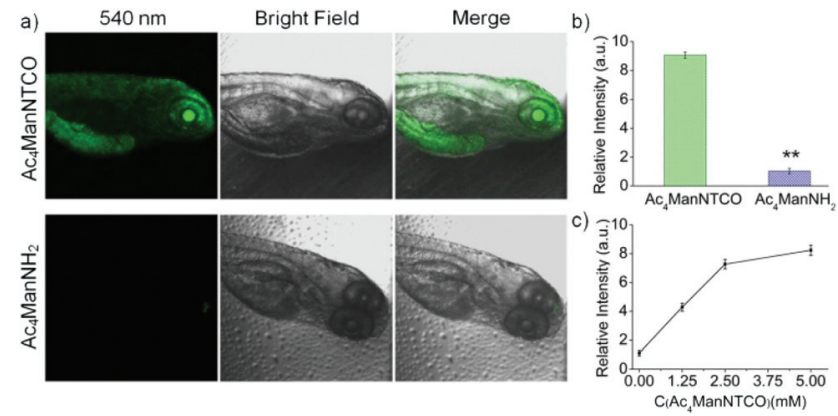

Fig. 4 (a) Two-photon emission images of the $\mathrm{Ac}_{4}$ ManNTCO (top row) or $\mathrm{Ac}_{4} \mathrm{ManNH}_{2}$ (bottom row) labelled zebrafish embryo at $72 \mathrm{~h}$ after fertilization. (b) Corresponding quantified intensity from (a). (c) Plots of the dose-dependent generation of TCO groups on the zebrafish after treatment with varied concentrations of $\mathrm{Ac}_{4}$ ManNTCO.

membranes of zebrafish pre-labeled with TCO-sialic acid, whereas there was no significant emission in control groups treated with $\mathrm{Ac}_{4} \mathrm{ManNH}_{2}$. And dose-dependent staining was observed in fishes treated with $0-5 \mathrm{mM} \mathrm{Ac}_{4} \mathrm{ManNTCO}$ (Fig. $4 \mathrm{c}$ and Fig. S27†). As a consequence, $\mathbf{T b} \mathbf{- 1}$ could be used as a valuable and efficient luminogenic probe for TCO-labelled glycomes in vivo via a two-step imaging procedure.

\section{Conclusions}

In conclusion, we have presented a terbium(III) complex Tb-1 as a novel luminogenic bioorthogonal probe. The probe is weakly emissive due to luminescence resonance energy transfer (LRET) to the tetrazine group. However, it showed dramatic emission enhancement upon cycloaddition reaction with a strained cyclooctene by altering the tetrazine structure and regaining the antenna effect. Interestingly, this tetrazine complex was also identified as a luminogenic bioorthogonal label and imaging reagent for cyclooctene-modified glycomes. We hope that these results will pave the way for future sitespecific protein labelling and imaging in live cells.

\section{Experimental section}

\section{Materials and instruments}

Materials. $\mathrm{TbCl}_{3} \cdot 6 \mathrm{H}_{2} \mathrm{O}(99 \%)$, diethylenetriaminepentaacetic acid (DTPA, $\geq 98 \%$ ), $\mathrm{NaOH}(\geq 98 \%), N$-hydroxysuccinimide (NHS, $\geq 98 \%$ ), $\mathrm{LaCl}_{3} \cdot 7 \mathrm{H}_{2} \mathrm{O}$ (99.99\%), $N, N$-dimethylformamide (DMF, 99\%), dimethyl sulfoxide (DMSO, 99\%) and 1-ethyl-3-(3dimethylaminopropyl)carbodiimide hydrochloride (EDC, $\geq 98 \%$ ) were purchased from Aladdin Reagent, Ltd (Shanghai, China); and trans-3-hydroxyl-cyclooctene (TCO, $\geq 98 \%$ ) and TCO-NHS $(\geq 98 \%)$ were purchased from Ruixi Biological Technology Co., Ltd (Xi'an, China). CCK-8 was obtained from Dojindo (Japan). Dulbecco's modified Eagle's medium (DMEM) cell culture medium, fetal bovine serum, streptomycin, and penicillin were purchased from Thermo Fisher 
Scientific Co., Ltd (China). All chemicals used in this study were of analytical grade and reagents were used without further purification. The compound $\mathrm{Ac}_{4} \mathrm{ManNTCO}$ was prepared (Fig. S28a†) according to our previous literature. ${ }^{56} \mathrm{La}-\mathrm{H}$ and La-1 were introduced via coordinating between the central atom lanthanum ion $\left(\mathrm{La}^{3+}\right)$ and the ligand of $\mathbf{T b}-\mathbf{M}$ and $\mathbf{T b} \mathbf{b} \mathbf{- 1}$, respectively (Fig. S28b $\dagger$ ). All aqueous solutions were prepared using ultrapure deionized water (DI water), which was obtained through a Millipore Milli-Q water purification system (Billerica, USA) and had an electric resistance $>18.2 \mathrm{M} \Omega$.

Instruments and characterization. The ${ }^{1} \mathrm{H}$ NMR spectra were recorded on a Bruker Ultrashield 400 Plus NMR spectrometer. All chemical shifts are reported in the standard $\delta$ notation of parts per million. The UV-vis absorption spectra were recorded on a UVvis spectrometer (Lambda 35 UV-vis spectrometer, PerkinElmer, USA) at room temperature. The emission lifetime measurements of $\mathbf{T b} \mathbf{- 1}$ and $\mathbf{T b} \mathbf{b} \mathbf{M}$ were recorded with a FLS-1000 fluorescence spectrophotometer (Edinburgh Instruments, Britain). High-performance liquid chromatography (HPLC) with absorbance detection was carried out using an Agilent7890B column and acetonitrile as the eluent. FT-IR spectra were recorded with $\mathrm{KBr}$ pellets on a Bio-Rad FTS 6000 spectrometer (Bio-Rad Company, Hercules, California, USA) at room temperature. The confocal fluorescence images of cell and zebrafish were collected on an Olympus FluoView FV10 microscope (Olympus Imaging America Inc., Japan). Cell viability was measured using a microplate reader (Infinite 200, Tecan, Switzerland).

Synthesis of compound 1. 4-[(1,2,4,5-Tetrazin-3-yl)phenyl]methanamine (tetrazine-benzylamine) and 7-amino-1,2dihydro-2-oxo-4-quinoline acetic acid were produced according to the literature, respectively. ${ }^{57,58}$ Quinolinone acid $(21.8 \mathrm{mg}$, $0.1 \mathrm{mmol}$ ) was reactivated with $N$-hydroxysuccinimide by adding 1.2 equiv. of NHS (13.8 $\mathrm{mg}, 0.12 \mathrm{mmol}$ ) and 1.2 equiv. of DCC $(24.7 \mathrm{mg}, 0.12 \mathrm{mmol})$ in dry DMF and reacted for 2 hours at room temperature. 1.1 equiv. of tetrazine-benzylamine $(22.1 \mathrm{mg}, 0.11 \mathrm{mmol})$ was added to the above solution and stirred at room temperature until the reaction reached completion (monitored by TLC). DMF was removed by rotary evaporation, and the crude mixture was purified by silica gel column chromatography with $\mathrm{CH}_{2} \mathrm{Cl}_{2} / \mathrm{CH}_{3} \mathrm{CN}(3: 1-1: 1$, v/v) as the eluent yielding compound $1(27.5 \mathrm{mg}, 68.5 \%) .{ }^{1} \mathrm{H} \mathrm{NMR}$ (400 MHz, d $\mathrm{d}_{6}$-DMSO): $\delta 11.23(\mathrm{~s}, 1 \mathrm{H}), 8.74(\mathrm{t}, J=4.0 \mathrm{~Hz}, 2 \mathrm{H})$, $8.38(\mathrm{~d}, J=8.0 \mathrm{~Hz}, 2 \mathrm{H}), 7.49$ (d, $J=8.0 \mathrm{~Hz}, 2 \mathrm{H}), 7.42$ (d, $J=8.0$ $\mathrm{Hz}, 1 \mathrm{H}), 6.44$ (d, J = 8.0 Hz, 1H), 6.38 (s, 1H), 6.05 (s, 1H), 5.74 (d, $J=4.0 \mathrm{~Hz}, 2 \mathrm{H}), 4.41$ (d, $J=4.0 \mathrm{~Hz}, 2 \mathrm{H}), 2.99$ (s, 3H). ESI-MS (m/z): calcd for $\mathrm{C}_{21} \mathrm{H}_{19} \mathrm{~N}_{7} \mathrm{O}_{2}, 401.42[\mathrm{M}]$; found, 402.2000.

Synthesis of compound 2. 1 equiv. of DTPA dianhydride (19.7 $\mathrm{mg}, 0.05 \mathrm{mmol}$ ) was dissolved in a mixture of DMSO, and 5 equiv. of $\mathrm{Et}_{3} \mathrm{~N}(34 \mathrm{~mL})$ under $\mathrm{N}_{2}$. 0.7 equiv. of compound 1 (14.1 $\mathrm{mg}, 0.035 \mathrm{mmol}$ ) dissolved in DMSO was added slowly to the above solution under vigorous stirring. The reaction mixture was stirred at room temperature for $2 \mathrm{~h}$. After completion, the above solution was quenched by addition of $0.1 \mathrm{M}$ $\mathrm{HCl}$ and $\mathrm{pH}$ was adjusted to 6.5. Then water was removed by rotary evaporation and the crude mixture was purified by ether precipitation yielding compound 2. ${ }^{1} \mathrm{H}$ NMR $\left(400 \mathrm{MHz}, \mathrm{d}_{6}\right.$ -
DMSO): $\delta 11.23(\mathrm{~s}, 1 \mathrm{H}), 7.95-8.54(\mathrm{~m}, 7 \mathrm{H}), 7.51(\mathrm{~d}, J=4.0 \mathrm{~Hz}$, $1 \mathrm{H}), 7.35(\mathrm{~d}, J=4.0 \mathrm{~Hz}, 1 \mathrm{H}), 6.42(\mathrm{~d}, J=8.0 \mathrm{~Hz}, 2 \mathrm{H}), 6.35(\mathrm{~s}$, $1 \mathrm{H}), 5.98(\mathrm{~d}, J=8.0 \mathrm{~Hz}, 1 \mathrm{H}), 4.38(\mathrm{~d}, J=4.0 \mathrm{~Hz}, 1 \mathrm{H}), 3.12(\mathrm{~d}, J=$ $8.0 \mathrm{~Hz}, 8 \mathrm{H}), 2.43(\mathrm{~d}, J=4.0 \mathrm{~Hz}, 2 \mathrm{H}), 2.36(\mathrm{~s}, 2 \mathrm{H}), 1.79(\mathrm{~s}, 4 \mathrm{H})$, $1.23(\mathrm{~s}, 2 \mathrm{H}), 2.36(\mathrm{t}, J=8.0 \mathrm{~Hz}, 1 \mathrm{H})$. ESI-MS $(\mathrm{m} / \mathrm{z})$ : calcd for $\mathrm{C}_{35} \mathrm{H}_{40} \mathrm{~N}_{10} \mathrm{O}_{11}, 776.75$ [M]; found, 776.4000.

Synthesis of Tb-1. Addition of metals: $\mathrm{TbCl}_{3} \cdot 6 \mathrm{H}_{2} \mathrm{O}(5.0 \mathrm{mg}$, $0.01 \mathrm{mmol}$ ) was added to compound $2(15.4 \mathrm{mg}, 0.02 \mathrm{mmol})$ in a $\mathrm{DMSO} / \mathrm{H}_{2} \mathrm{O}(2: 1, \mathrm{v} / \mathrm{v})$ solution, and $\mathrm{pH}$ was adjusted to 6.5 by addition of $0.1 \mathrm{M} \mathrm{HCl}, \mathrm{pH} 6.5$ buffer, and stirred for $3 \mathrm{~h}$ at room temperature. Then the water was removed by rotary evaporation and the crude mixture purified by ether precipitation affording Tb-1. ESI-MS $(\mathrm{m} / \mathrm{z})$ : calcd for $\mathrm{C}_{35} \mathrm{H}_{36} \mathrm{~N}_{10} \mathrm{O}_{11} \mathrm{~Tb}^{3+}$, $931.64[\mathrm{M}]$; found, 931.3000.

Calculation of the limit of detection (LOD). LOD was calculated using the formula, ${ }^{48} \mathrm{LOD}=3 \delta / k$. Here, $\delta$ represents the standard deviation of the fluorescence intensity of 3 blank solutions, and $k$ represents the slope between fluorescence intensity and concentration.

Stability of Tb-1. The stability of Tb-1 in the simulated physiological environment was detected as below: Tb-1 solution containing 0 to $50 \%$ serum $(\mathrm{pH}=7.4)$ in $\mathrm{PBS}(\mathrm{pH} 7.4)$ were kept for different times (from 1 to $24 \mathrm{~h}$ ). The luminescence emission spectra were then recorded.

Cell culture. Human lung adenocarcinoma cells (A549) and experimental mammary tumour-6 cells (EMT 6) were cultured in DMEM or normal human hepatic cell (LO2) were cultured in RIM1640 containing 10\% fetal bovine serum and 1\% penicillin/streptomycin at $37{ }^{\circ} \mathrm{C}$ in a humidified $5 \% \mathrm{CO}_{2}$ atmosphere. The cell density was determined using a hemocytometer before experimentation.

Cytotoxicity evaluation in vitro. Relative cell viabilities were determined by the standard CCK-8 assay. A549 cells and EMT6 or LO2 cells were seeded into 96 -well plates $\left(1 \times 10^{4}\right.$ cells per well). And the cells were cultured for $12 \mathrm{~h}$ at $37^{\circ} \mathrm{C}$ in a humidified incubator, $100 \mu \mathrm{L}$ different concentrations of Tb-1 PBS ( $\mathrm{pH}$ 7.4) solution were added into the wells. After this, the cells were incubated for another $12 \mathrm{~h}$ at $37^{\circ} \mathrm{C}$. Then the cells were washed using PBS buffer to remove the unbound compound, and fresh culture medium was added. After incubation at $37{ }^{\circ} \mathrm{C}$ for $12 \mathrm{~h}$, solution containing 10\% CCK-8 DMEM $(100 \mu \mathrm{L})$ was added to these cells. After incubation for $2 \mathrm{~h}$ at $37{ }^{\circ} \mathrm{C}$, OD450, the absorbance value at $450 \mathrm{~nm}$, were measured with a microplate reader to determine cell viability.

Imaging glycans with cells. A549 cells were first pretreated with $\mathrm{Ac}_{4} \mathrm{ManNH}_{2}(50 \mu \mathrm{M})$ or $\mathrm{Ac}_{4} \mathrm{ManNTCO}(50 \mu \mathrm{M})$ for 3 days and washed with PBS ( $\mathrm{pH}$ 7.4) twice. This was followed by incubation with Tb-1 $(50 \mu \mathrm{M})$ for $3 \mathrm{~h}$ at $37^{\circ} \mathrm{C}$ in a humidified incubator and images were obtained using an Olympus FluoView FV10 microscope (Olympus Imaging America Inc., Japan) without washing. The two-photon excited luminescence of $\mathrm{Tb}^{3+}$ by a $730 \mathrm{~nm}$ laser was recorded at 500-560 $\mathrm{nm}$.

Western blot analysis of cells. A549 cells were pretreated with $\mathrm{Ac}_{4} \mathrm{ManNH}_{2}(50 \mu \mathrm{M})$ or $\mathrm{Ac}_{4}$ ManNTCO $(50 \mu \mathrm{M})$ for 3 days and washed with PBS ( $\mathrm{pH}$ 7.4) twice, then harvested from the plates and centrifuged at $1800 \mathrm{rpm}$ for $3 \mathrm{~min}$. The cells were 
resuspended and incubated in $100 \mu \mathrm{L}$ of lysis buffer (1\% SDS, $100 \mathrm{mM}$ Tris $\cdot \mathrm{HCl}, \mathrm{pH}$ 7.4) containing a protease inhibitor cocktail (Complete, EDTA-free) at $4{ }^{\circ} \mathrm{C}$ for $30 \mathrm{~min}$ and centrifuged for $20 \mathrm{~min}$ at $11000 \mathrm{rpm}$ to get supernatant solution. The solution lysates $\left(5 \mathrm{mg} \mathrm{mL}{ }^{-1}, 50 \mu \mathrm{L}\right)$ were incubated with tetrazine-biotin ( $5 \mu \mathrm{L}, 5 \mathrm{mM}$ in DPBS) for $6 \mathrm{~h}$ at $37^{\circ} \mathrm{C}$. Then the samples were resolved by $12 \%$ SDS/PAGE and transferred to pure nitrocellulose blotting membranes (BioTrace NT; Pall Life Science, Pensacola, FL, USA). The membranes were blocked using $10 \mathrm{mM}$ Tris/HCl ( $\mathrm{pH}$ 7.4), $150 \mathrm{mM} \mathrm{NaCl}$, and $0.1 \%$ Tween-20 containing $5 \%$ nonfat milk for $1.5 \mathrm{~h}$. Then, the membrane was incubated with streptavidin-HRP (diluted $1: 2000$ in TBST) overnight at $4{ }^{\circ} \mathrm{C}$. The membrane was developed using a HPR-AEC western blotting substrate.

Flow cytometry analysis. A549 cells were pretreated with $\mathrm{Ac}_{4}$ ManNTCO $(50 \mu \mathrm{M})$ or $\mathrm{Ac}_{4} \mathrm{ManNH}_{2}(50 \mu \mathrm{M})$ followed by tetrazine-FITC. Then, the cells were removed and washed with FACS buffer. 10000 cells per sample were analysed on a FACS canto II flow cytometer (Becton Dickinson, Mountain View, CA, USA) with excitation at $488 \mathrm{~nm}$.

Imaging glycans with zebrafish. All animal experiments were performed in compliance with the National Institutes of Health (NIH) guidelines for the Care and Use of Laboratory Animals of South China Normal University, and the experiments were approved by the Animal Ethics Committee of South China Normal University. Zebrafish Husbandry: adult wild-type zebrafish were maintained at $28.5{ }^{\circ} \mathrm{C}$ on a 14 hour light and 10 hour dark cycle. Embryos were obtained from natural spawning and were maintained in embryo medium (EM; $150 \mathrm{mM} \mathrm{NaCl}, 0.5 \mathrm{mM} \mathrm{KCl}, 1.0 \mathrm{mM} \mathrm{CaCl}, 0.37 \mathrm{mM}$ $\mathrm{KH}_{2} \mathrm{PO}_{4}, 0.05 \mathrm{mM} \mathrm{Na} 2 \mathrm{HPO}_{4}, 2.0 \mathrm{mM} \mathrm{MgSO}$, and $0.71 \mathrm{mM}$ $\mathrm{NaHCO}_{3}$ in deionized water, $\mathrm{pH}$ 7.4). ${ }^{59}$

Zebrafish embryos at the one-cell stage were dechorionated by $1 \mathrm{mg} \mathrm{mL} L^{-1}$ protease $\left(1 \mathrm{mg} \mathrm{mL} L^{-1}\right.$ in embryo medium) at 4 hours post-fertilization (hpf). And then these embryos were microinjected into the yolk with $5 \mathrm{~nL}$ of $5 \mathrm{mM} \mathrm{Ac}_{4}$ ManNTCO. Meanwhile, the embryos microinjected with $5 \mathrm{~nL}$ of $5 \mathrm{mM}$ $\mathrm{Ac}_{4} \mathrm{ManNH}_{2}$ were used as control groups. The embryos were then cultured at $28^{\circ} \mathrm{C}$ using the standard embryo culture protocol. PTU $(131 \mu \mathrm{M})$ was included in the medium beginning at $12 \mathrm{hpf}$ to inhibit melanin production. After $72 \mathrm{hpf}$, they were labeled with the TCO group on zebrafish using a similar strategy to that of cellular glycome labeling described above. The embryos were then removed from the $\mathrm{Ac}_{4} \mathrm{ManNTCO}$ or $\mathrm{Ac}_{4} \mathrm{ManNH}_{2}$ containing solution, rinsed, and incubated in embryo medium containing Tb-1 $(100 \mu \mathrm{M})$ for $3 \mathrm{~h}$ at $28{ }^{\circ} \mathrm{C}$. The embryos were anesthetized with tricaine $(2.6 \mu \mathrm{M}$ in embryo medium) and mounted between two cover slips in embryo medium containing $0.6 \%$ low melting point agarose, $2.6 \mu \mathrm{M}$ tricaine, and $131 \mu \mathrm{M}$ PTU. After this, the embryos were detected using microscopy with excitation at $730 \mathrm{~nm}$.

\section{Conflicts of interest}

There are no conflicts to declare.

\section{Acknowledgements}

This research was supported by the National Natural Science Foundation of China (21771065), the Guangdong Special Support Program (2017TQ04R138), the Science and Technology Program of Guangzhou (2019050001), the Natural Science Foundation of Guangdong (2019A1515012021), the Pearl River Nova Program of Guangzhou, Guangdong Province, China (201806010189), the Hong Kong Research Grants Council (HKBU1230019) and the Hong Kong Baptist University (RC-ICRS/18-19/01), and CAS-Croucher Funding Scheme for Joint Laboratories (CAS 18204).

\section{References}

1 J. A. Prescher and C. R. Bertozzi, Chemical Technologies for Probing Glycans, Cell, 2006, 126, 851-854.

2 J. A. Prescher and C. R. Bertozzi, Chemistry in Living Systems, Nat. Chem. Biol., 2005, 1, 13-21.

3 J. D. Keasling, Manufacturing molecules through metabolic engineering, Science, 2010, 330, 1355-1358.

4 P. V. Chang, J. A. Prescher, M. J. Hangauer and C. R. Bertozzi, Imaging cell surface glycans with bioorthogonal chemical reporters, J. Am. Chem. Soc., 2007, 129, 8400-8401.

5 R. Xie, L. Dong, Y. Du, Y. Zhu, R. Hua, C. Zhang and $\mathrm{X}$. Chen, In vivo metabolic labeling of sialoglycans in the mouse brain by using a liposome-assisted bioorthogonal reporter strategy, Proc. Natl. Acad. Sci. U. S. A., 2016, 113, 5173-5178.

6 A. Shajahan, S. Parashar, S. Goswami, S. M. Ahmed, P. Nagarajan and S.-G. Sampathkumar, Carbohydrate-neuroactive hybrid strategy for the metabolic glycan engineering of the central nervous system in vivo, J. Am. Chem. Soc., 2017, 139, 693-700.

7 H. Wang, R. Wang, K. Cai, H. He, Y. Liu, J. Yen, Z. Wang, M. Xu, Y. Sun, X. Zhou, Q. Yin, L. Tang, I. T. Dobrucki, L. W. Dobrucki, E. J. Chaney, S. A. Boppart, T. M. Fan, S. Lezmi, X. Chen, L. Yin and J. Cheng, Selective in vivo metabolic cell-labeling-mediated cancer targeting, Nat. Chem. Biol., 2017, 13, 415-424.

8 D. Zhang, Y. S. Zheng, Z. Lin, X. L. Liu, J. Li, H. H. Yang and W. H. Tan, Equipping natural killer cells with specific targeting and checkpoint blocking aptamers for enhanced adoptive immunotherapy in solid tumors, Angew. Chem., Int. Ed., 2020, 59, 12022-12028.

9 J. Hassenruck and V. Wittmann, Cyclopropene derivatives of aminosugars for metabolic glycoengineering, Beilstein J. Org. Chem., 2019, 15, 584-601.

10 C. P. Ramil and Q. Lin, Bioorthogonal chemistry: Strategies and recent developments, Chem. Commun., 2013, 49, 11007-11022.

11 P. Shieh and C. R. Bertozzi, Design strategies for bioorthogonal smart probes, Org. Biomol. Chem., 2014, 12, 93079320. 
12 S. Stairs, A. A. Neves, H. Stöckmann, Y. A. Wainman, H. Ireland-Zecchini, K. M. Brindle and F. J. Leeper, Metabolic glycan imaging by isonitrile-tetrazine click chemistry, ChemBioChem, 2013, 14, 1063-1067.

13 J. Yang, J. Šečkutè, C. M. Cole and N. K. Devaraj, Live-cell imaging of cyclopropene tags with fluorogenic tetrazine cycloadditions, Angew. Chem., Int. Ed., 2012, 51, 7476-7479.

14 Y. Y. Yang, J. M. Ascano and H. C. Hang, Bioorthogonal chemical reporters for monitoring protein acetylation, J. Am. Chem. Soc., 2010, 132, 3640-3641.

15 X. L. Hu, H. Y. Jin, X. P. He, T. D. James, G. R. Chen and Y. T. Long, Colorimetric and plasmonic detection of lectins using core-shell gold glyconanoparticles prepared by copper-free click chemistry, ACS Appl. Mater. Interfaces, 2015, 7, 1874-1878.

16 A. Niederwieser, A.-K. Späte, L. D. Nguyen, C. Jüngst, W. Reutter and V. Wittmann, Two-color glycan labeling of live cells by a combination of diels-alder and click chemistry, Angew. Chem., Int. Ed., 2013, 52, 4265-4268.

17 M. F. Debets, S. S. van Berkel, J. Dommerholt, A. J. Dirks, F. P. J. T. Rutjes and F. L. van Delft, Bioconjugation with strained alkenes and alkynes, Acc. Chem. Res., 2011, 44, 805-815.

18 S. Bernard, D. Audisio, M. Riomet, S. Bregant, A. Sallustrau, L. Plougastel, E. Decuypere, S. Gabillet, R. A. Kumar, J. Elyian, M. N. Trinh, O. Koniev, A. Wagner, S. Kolodych and F. Taran, Bioorthogonal click and release reaction of iminosydnones with cycloalkynes, Angew. Chem., Int. Ed., 2017, 56, 15612-15616.

19 J. Dommerholt, S. Schmidt, R. Temming, L. J. A. Hendriks, F. P. J. T. Rutjes, J. C. M. van Hest, D. J. Lefeber, P. Friedl and F. L. van Delft, Readily accessible bicyclononynes for bioorthogonal labeling and three-dimensional imaging of living cells, Angew. Chem., Int. Ed., 2010, 49, 9422-9425.

20 D. M. Patterson, L. A. Nazarova, B. Xie, D. N. Kamber and J. A. Prescher, Functionalized cyclopropenes as bioorthogonal chemical reporters, J. Am. Chem. Soc., 2012, 134, 18638-18643.

21 S. Letschert, A. Göhler, C. Franke, N. Bertleff-Zieschang, E. Memmel, S. Doose, J. Seibel and M. Sauer, Super-resolution imaging of plasma membrane glycans, Angew. Chem., Int. Ed., 2014, 53, 10921-10924.

22 C. Witte, V. Martos, H. M. Rose, S. Reinke, S. Klippel, L. Schröder and C. P. R. Hackenberger, Live-cell MRI with xenon hyper-cest biosensors targeted to metabolically labeled cell-surface glycans, Angew. Chem., Int. Ed., 2015, 54, 2806-2810.

23 M. Sawa, T. L. Hsu, T. Itoh, M. Sugiyama, S. R. Hanson, P. K. Vogt and C. H. Wong, Glycoproteomic probes for fluorescent imaging of fucosylated glycans in vivo, Proc. Natl. Acad. Sci. U. S. A., 2006, 103, 12371-12376.

24 S. T. Laughlin, J. M. Baskin, S. L. Amacher and C. R. Bertozzi, In vivo imaging of membrane-associated glycans in developing zebrafish, Science, 2008, 320, 664.

25 S. Park, J. W. Sung and I. Shin, Fluorescent Glycan derivatives: Their use for natural glycan microarrays, ACS Chem. Biol., 2009, 4, 699-701.
26 H. Stöckmann, A. A. Neves, S. Stairs, H. Ireland-Zecchini, K. M. Brindle and F. J. Leeper, Development and evaluation of new cyclooctynes for cell surface glycan imaging in cancer cells, Chem. Sci., 2011, 2, 932-936.

27 M. C. Heffern, L. M. Matosziuk and T. J. Meade, Lanthanide probes for bioresponsive imaging, Chem. Rev., 2014, 114, 4496-4539.

28 T. Zhang, X. Zhu, C. C. W. Cheng, W.-M. Kwok, H. L. Tam, J. Hao, D. W. J. Kwong, W.-K. Wong and K.-L. Wong, Watersoluble mitochondria-specific ytterbium complex with impressive NIR emission, J. Am. Chem. Soc., 2011, 133, 20120-20122.

29 D. Kovacs, X. Lu, L. S. Mészáros, M. Ott, J. Andres and K. E. Borbas, Photophysics of coumarin and carbostyrilsensitized luminescent lanthanide complexes: implications for complex design in multiplex detection, J. Am. Chem. Soc., 2017, 139, 5756-5767.

30 E. M. Surender, S. J. Bradberry, S. A. Bright, C. P. McCoy, D. C. Williams and T. Gunnlaugsson, Luminescent lanthanide cyclen-based enzymatic assay capable of diagnosing the onset of catheter-associated urinary tract infections both in solution and within polymeric hydrogels, J. Am. Chem. Soc., 2017, 139, 381-388.

31 H. M. Burke, T. Gunnlaugsson and E. M. Scanlan, Glycosylated lanthanide cyclen complexes as luminescent probes for monitoring glycosidase enzyme activity, Org. Biomol. Chem., 2016, 14, 9133-9145.

32 K. Y. Zhang, Q. Yu, H. Wei, S. Liu, Q. Zhao and W. Huang, Long-lived emissive probes for time-resolved photoluminescence bioimaging and biosensing, Chem. Rev., 2018, 118, 1770-1839.

33 J. Zheng, Y. Wu, D. Xing and T. Zhang, Synchronous detection of glutathione/hydrogen peroxide for monitoring redox status in vivo with a ratiometric upconverting nanoprobe, Nano Res., 2019, 12, 931-938.

34 S. F. Xue, Z. H. Chen, X. Y. Han, Z. Y. Lin, Q. X. Wang, M. Zhang and G. Shi, DNA encountering terbium(III): A smart "Chemical nose/tongue" For large-scale time-gated luminescent and lifetime-based sensing, Anal. Chem., 2018, 90, 3443-3451.

35 J. C. G. Bünzli, Lanthanide luminescence for biomedical analyses and imaging, Chem. Rev., 2010, 110, 2729-2755.

36 D. Jin and J. A. Piper, Time-gated luminescence microscopy allowing direct visual inspection of lanthanide-stained microorganisms in background-free condition, Anal. Chem., 2011, 83, 2294-2300.

37 A. B. Aletti, D. M. Gillen and T. Gunnlaugsson, Luminescent/colorimetric probes and (chemo-) sensors for detecting anions based on transition and lanthanide ion receptor/binding complexes, Coord. Chem. Rev., 2018, 354, 98-120.

38 H. Stockmann, V. Todorovic, P. L. Richardson, V. Marin, V. Scott, C. Gerstein, M. Lake, L. Wang, R. Sadhukhan and A. Vasudevan, Cell-surface receptor-ligand interaction analysis with homogeneous time-resolved fret and metabolic glycan engineering: Application to transmembrane and 
gpi-anchored receptors, J. Am. Chem. Soc., 2017, 139, 16822-16829.

39 X. Ai, L. Lyu, Y. Zhang, Y. Tang, J. Mu, F. Liu, Y. Zhou, Z. Zuo, G. Liu and B. Xing, Remote regulation of membrane channel activity by site-specific localization of lanthanidedoped upconversion nanocrystals, Angew. Chem., Int. Ed., 2017, 56, 3031-3035.

40 L. Ruhe, S. Ickert, S. Beck and M. W. Linscheid, A new strategy for metal labeling of glycan structures in antibodies, Anal. Bioanal. Chem., 2018, 410, 21-25.

41 A. Beeby, I. M. Clarkson, R. S. Dickins, S. Faulkner, D. Parker, L. Royle, A. S. de Sousa, J. A. Gareth Williams and M. Woods, Non-radiative deactivation of the excited states of europium, terbium and ytterbium complexes by proximate energy-matched $\mathrm{OH}, \mathrm{NH}$ and $\mathrm{CH}$ oscillators: an improved luminescence method for establishing solution hydration states, J. Chem. Soc., Perkin Trans. 2, 1999, 493504.

42 W. D. Horrocks Jr. and D. R. Sudnick, Lanthanide ion probes of structure in biology. Laser-induced luminescence decay constants provide a direct measure of the number of metal-coordinated water molecules, J. Am. Chem. Soc., 1979, 101, 334-340.

43 J. C. de Mello, H. F. Wittmann and R. H. Friend, An improved experimental determination of external photoluminescence quantum efficiency, Adv. Mater., 1997, 9, 230-232.

44 A. Wieczorek, T. Buckup and R. Wombacher, Rigid tetrazine fluorophore conjugates with fluorogenic properties in the inverse electron demand diels-alder reaction, Org. Biomol. Chem., 2014, 12, 4177-4185.

$45 \mathrm{H}$. Wu and N. K. Devaraj, Advances in tetrazine bioorthogonal chemistry driven by the synthesis of novel tetrazines and dienophiles, Acc. Chem. Res., 2018, 51, 12491259.

46 P. Miluskia, M. Kochanowicz, J. Zmojdaa, A. Baranowska and D. Dorosz, Energy transfer of $\mathrm{Tb}(\mathrm{tmhd})_{3}$-Rhodamine B in poly(methyl methacrylate) fiber for new photonic applications, Opt. Mater., 2019, 87, 132-138.

47 J. B. M. R. Filho, P. R. Santos, J. A. Vale, W. M. Faustino, D. S. Farias, H. F. Brito, M. C. F. C. Felinto and E. E. S. Teotonio, Rare Earth-Indomethacinate Complexes with Heterocyclic Ligands: Synthesis and Photoluminescence Properties, J. Braz. Chem. Soc., 2017, 12, 2281-2290.
48 X. H. Pan, Y. H. Zhao, T. T. Cheng, A. S. Zheng, A. B. Ge, L. X. Zang, K. H. Xu and B. Tang, Monitoring NAD(P)H by an ultrasensitive fluorescent probe to reveal reductive stress induced by natural antioxidants in HepG2 cells under hypoxia, Chem. Sci., 2019, 10, 8179-8186.

49 A. C. Knall and C. Slugovc, Inverse electron demand dielsalder (iedda)-initiated conjugation: a (high) potential click chemistry scheme, Chem. Soc. Rev., 2013, 42, 5131-5142.

50 U. Rieder and N. W. Luedtke, Alkene-Tetrazine Ligation for Imaging Cellular DNA, Angew. Chem., Int. Ed., 2014, 53, 9168-9172.

51 E. M. Surender, S. Comby, B. L. Cavanagh, O. Brennan, T. C. Lee and T. Gunnlaugsson, Two-photon luminescent bone imaging using europium nanoagents, Chem, 2016, 1, 438-455.

52 M. J. Davis, C. H. Kragor, K. G. Reddie, H. C. Wilson, Y. Zhu and T. M. Dore, Substituent effects on the sensitivity of a quinoline photoremovable protecting group to oneand two-photon excitation, J. Org. Chem., 2009, 74, 17211729.

53 X. Y. Chen, J. Shi, Y. M. Li, F. L. Wang, X. Wu, Q. X. Guo and L. Liu, Two-photon fluorescent probes of biological zn (II) derived from 7-hydroxyquinoline, Org. Lett., 2009, 11, 4426-4429.

54 Y. Mikata, A. Yamanaka, A. Yamashita and S. Yano, Isoquinoline-based TQEN family as TPEN-derived fluorescent zinc sensors, Inorg. Chem., 2008, 47, 7295-7301.

55 S. K. Ko, X. Chen, J. Yoon and I. Shin, Zebrafish as a good vertebrate model for molecular imaging using fluorescent probes, Chem. Soc. Rev., 2011, 40, 2120-2130.

56 R. J. Zhang, J. D. Zheng and T. Zhang, In vivo selective imaging of metabolic glycosylation with a tetrazine-modified upconversion nanoprobe, $R S C A d v$., 2020, 10, 1599015996.

57 H.-S. Han, N. K. Devaraj, J. Lee, S. A. Hilderbrand, R. Weissleder and M. G. Bawendi, Development of a bioorthogonal and highly efficient conjugation method for quantum dots using tetrazine-norbornene cycloaddition, J. Am. Chem. Soc., 2010, 132, 7838-7839.

58 P. Ge and P. R. Selvin, Carbostyril derivatives as antenna molecules for luminescent lanthanide chelates, Bioconjugate Chem., 2004, 15, 1088-1094.

59 Y. Wu, G. Guo, J. Zheng, D. Xing and T. Zhang, Fluorogenic "photoclick" Labeling and imaging of dna with coumarinfused tetrazole in vivo, ACS Sens., 2019, 4, 44-51. 